$12-29-2017$

\title{
Intervention to indoor air-pollution in Timor Tengah Selatan, Indonesia
}

\author{
Rachmadhi Purwana \\ Faculty of Public Health Universitas Indonesia, rachmadhi@hotmail.com \\ Budi Hartono \\ Faculty of Public Health Universitas Indonesia
}

See next page for additional authors

Follow this and additional works at: https://scholarhub.ui.ac.id/ajce

Part of the Social and Behavioral Sciences Commons

\section{Recommended Citation}

Purwana, Rachmadhi; Hartono, Budi; and Tahun, Omega DR (2017). Intervention to indoor air-pollution in Timor Tengah Selatan, Indonesia. ASEAN Journal of Community Engagement, 1(2).

Available at: https://doi.org/10.7454/ajce.v1i2.90

Creative Commons License

(c) (i) ()

This work is licensed under a Creative Commons Attribution-Share Alike 4.0 License.

This Research Article is brought to you for free and open access by the Universitas Indonesia at ASEAN Journal of Community Engagement. It has been accepted for inclusion in ASEAN Journal of Community Engagement. 


\title{
Intervention to Indoor Air-pollution in Timor Tengah Selatan, Indonesia
}

\author{
Rachmadhi Purwana ${ }^{a}$, Budi Hartonoa, Omega DR Tahun ${ }^{\mathrm{b}}$ \\ ${ }^{a}$ Faculty of Public Health, Universitas Indonesia \\ ${ }^{b}$ STIKES Abdi Nusantara, Jakarta, Indonesia
}

Received: October 27th 2017 || Revised: November 30th 2017 || Accepted: December 12 $2^{\text {th }}, 2017$

\begin{abstract}
Preliminary research in 2012 indicated that the prevalence of Acute Respiratory Infections (ARI) among children under-five in Nusa Tenggara Timur (NTT) Province, Indonesia, was related to the high concentration of indoor $\mathrm{PM}_{10}$ from the burning of wood on simple stoves in traditional huts (Ume Kbubu). Out of the data obtained, a CEGs action research was done in 2013. Smoke produced from wood burning stoves inside the Ume Kbubu tends to flow up higher into the air in the confined room of the traditional huts. An application of partition and chimney upon the stoves was expected to drive the smoke to the upper part of the hut to mitigate the exposure to indoor smoke pollution for the inhabitants of the huts. Engaging the local community, an action-research using an observational cross-sectional data collection was done in 3 Sub-districts of Nunkolo, Oinlasi, and Kuanfatu, District of Timor Tengah Selatan, NTT. The action-research combined the use of a questionnaire, the measurement of the level of indoor air pollution by examining the $\mathrm{PM}_{10}$ and $\mathrm{CO}$ concentrations, the delivery of a general health education program, and the application of a room-partition and a chimney in each of Ume Kbubu selected. A higher concentration of $\mathrm{PM}_{10}(9.69 \pm 8.8 \mathrm{ppm})$ was found inside the traditional huts at the height of $11 / 2$ meter as compared to 4.39 $\pm 5.82 \mathrm{ppm}$ at the height of $1 / 2$ meter examination points. This a sign that the smoke tends to concentrate on the higher level within a room. A significant health risks level of CO (86.2 $\pm 53.42 \mathrm{ppm})$ were also found. By driving the smoke through the application of partition and chimney upon the stove in the traditional huts, the research found a prospectively effective measure to control indoor air pollution in reducing the exposure of the inhabitants from smoke in the traditional huts. From the questionnaire, it was found that water collection was also a burden for the household members. The application of chimney and room-partition gave a promising improvement in the effort to mitigate the exposure of the inhabitant from the indoor air pollution in the traditional huts of Timor Tengah Selatan.
\end{abstract}

Keywords: ARI; indoor-air pollution; $\mathrm{PM}_{10}$; wood smoke; traditional huts

\section{Introduction}

ARI was one of the leading causes of deaths among children under five in developing countries. Many types of research related ARI with air contaminants. A continuous supply of ten to twenty cubic meters of air of acceptable quality was essential and fundamental for human life (WHO, 2010). Meanwhile, around two million people worldwide die each year from ARI due to the use of traditional biomass and coal stoves. This includes 1 million deaths in children under the age of five (WHO-UNICEF, 2004). The figures of this situation in the developing countries might even be more significantly appalling considering that the daily lives of people in these countries were still below the reasonably accepted standard of living in other parts of the world. This assumption could be seen in remote areas in Indonesia where social and economic activity did not support the healthy lives of the native of the areas. Nationwide, it is reported that $64.2 \%$ of fuel sources were charcoal and wood especially in the rural areas (Depkes, 2010).

Report by the Ministry of Health Indonesia in 2007 showed the prevalence rate of ARI in the Province of Nusa Tenggara Timur (NTT) was $41.36 \%$, --the highest throughout the country-- nearly two times of the National ARI prevalence rate $(25.50$ $\%)$. ARI mortality rate among babies in the area was $23.8 \%$ and among children under five was $15.5 \%$ (Depkes, 2007). In the District of Timor Tengah Selatan (TTS) of NTT 
Province, ARI was commonly found among children under five. In 2007, there were 136,051 cases of ARI ( $28.5 \%$ of the total ten leading diseases in the local Health Centre) (Dinkes TTS, 2007).

The District of TTS was in the southern part of central Timor Island occupying an area of 3,947 $\mathrm{km}^{2}$ with 23 Districts and a hilly terrain with a slope of approximately 50 $\%$. Geographically the TTS District resided between the east longitudes $124.4^{\circ}-124.49^{\circ}$ and south latitudes of $9.24^{\circ}-10.00^{\circ}$. At the time of the research, roads and means of transportation were limited and beyond the decently expected quality.

Almost all the people in the villages of the District lived in traditional dome-shaped huts with a diameter of 3 to 4 meters, made of and covered with wild grasses and twigs. Access to the hut was only through an opening approximately 1 meter high and 0.70meter- wide; only sufficient for an adult to pass through. No windows or any other openings were made available for ventilation. This is because it was traditionally indoctrinated shape of the hut and the outside weather was cold. Inside, a traditional simple stove made of three or more stones put together for burning woods was used for 2 to 20 hours a day with no smoke hood.

Public services in the village were the Village Health Centre, Office of the Head Village, Religious Facility, Primary Schools, and Secondary Schools. Ten prominent diseases recorded by the Village Health Centre including acute respiratory infection, muscle and ligaments diseases, skin infections, diarrhea, gastritis, other upper respiratory tract diseases, allergic skin diseases, accidents and injuries, and others.

Research done in 2012 found that the prevalence of ARI among children under five was related to high concentration of indoor $\mathrm{PM}_{10}$ concentration from the burning of wood in stoves in the traditional huts (Purwana, et al., 2012). Most of the villagers in this area still rely on wood, a typical form of unprocessed biomass fuel easily found in the vicinity for their daily use of energy for cooking, warmth, and light. Due to the structure of the traditional huts that devoid of effective ventilation, the whole single room of the hut was nearly always full of smoke. The examination in a hundred units of traditional huts showed a mean concentration of $2.724 \pm 2.979 \mathrm{mg} / \mathrm{m}^{3} \mathrm{PM}_{10}$ (a range of 0.050 to $16.150 \mathrm{mg} / \mathrm{m}^{3}$ ). As much as $58 \%$ of 100 respondents in the above-mentioned research had only a preliminary education level. They did not have the real concern about the health effect of ARI due to the wood smoke. Out of all respondents, $97 \%$ had more concern of sore eyes due to smoke, and $99 \%$ thought that smoke was not a serious nuisance to health. To further figuring the seriousness of the problem, $69 \%$ of the respondent had their children under-fives and infants stayed around the cook-stove during cooking time. It was also reported that $73 \%$ of the respondents were willing to use chimneys or smoke hood for their stoves.

Based on these findings, a three-stage action researcher were proposed to deal with the indoor air pollution related to ARI in the traditional huts in NTT. The objectives of the first stage (present research) were primarily to find the acceptance of the villagers and the impacts of manipulating the indoor environment with a simple technology through the application of a room partition and a smoke hood or chimney over their traditional stoves. These were expected to be able to control the smoke concentration inside the traditional hut. A program of health education on sanitation and effects of indoor air pollution of wood smoke was also designed to raise the awareness of the indigenous people about the health effect of wood-smoke and to motivate them to live a better and healthier life by reducing indoor air pollution exposure from wood-burning stoves in their traditional huts. The other two stages of this serial research would focus more on the follow-up of the previous one. 
Specifically, this first stage of action research was a preliminary step to approach the native people of NTT who had lived their traditional way of life ever since unrecorded time. The action research was done in Nunkolo, Oinlasi, and Kuanfatu Sub-districts in the District of TTS, NTT Province. The three places were chosen based on the positive will of key persons in those places to be involved. Besides the primary objective of dealing with indoor air pollution, this research was also intended to have a first-hand picture and data of the demography and perception of the inhabitants over basic sanitation and indoor-air pollution. These were necessary to further understand the underlying factors of ARI and other environmentally related diseases among the villagers. Further, this research also intended to find a practical alternative to the use of other environmentally friendlier fuel and stove.

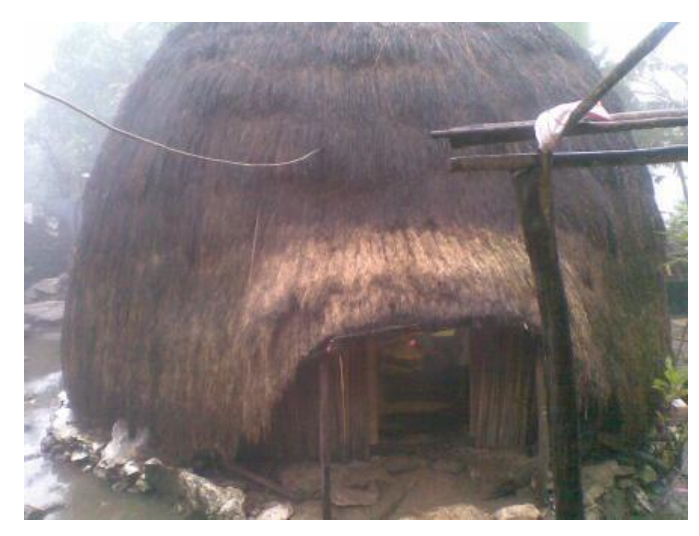

Fg. 1 Traditional Hut, Nusa Tenggara Timur (NTT)

Source: photo archive from Purwana R., et al., 2013

\section{Theoretical Background}

In a range of 25 to $33 \%$ of the global burden of disease can be attributed to environmental risk factors. Accordingly, children under five seem to bear the largest environmental burden (Smith KR. et al., 1999). These facts might be found in less developed communities.

Acute Respiratory Infections (ARI) was known globally as a serious disease of the respiratory tract. In developing countries, ARI was the leading cause of death in children (Denny FW., Loda FA., 1986). ARI were infections in upper and lower respiratory tract simultaneously or sequentially. It was the invasion of disease-causing agents --including bacteria and viruses,-- their multiplication, and the reaction of host tissues to the infectious agents and the toxins they produce. Symptoms can be mild to life-threatening. The most common symptoms can include coughing with or without mucus (phlegm), fever, sweating, chills, and shortness of breath (dyspnoea).

The smoke from solid fuel use was known as a risk factor for acute infections for the lower respiratory tract (ALRI) including pneumonia among children under five. Inhalation of indoor air pollution was reported as responsible for approximately 900,000 child deaths attributable to ALRI in 2004 (UNEP \& WHO, 2010). A systemic pathologic change was produced in the lung due to chronic inhalations of smoke. Incomplete combustion produced many metabolic toxins (Schiller WR.,2000). Occupants of confined spaces of huts in parts of less developed countries were reported to develop the "hut lung," or domestically acquired particulate lung disease (DAPLD) due to years of exposure to biomass smoke. Symptoms of a chronic cough, dyspnoea, and early parenchymal lung disease might have developed among them. Removal of the 
Rachmadi P., Budi H., Omega DR T. | ASEAN Journal of Community Engagement | Volume 1, Number 2, 2017

patient from the environment is the only treatment (Diaz JV. et al., 2006; Gold JA. et al., 2000; Grobbelaar JP., Bateman ED. 1991).

Inhalation of some by-products from the combustion of wood such as carbon monoxide (CO), oxides of nitrogen, Sulphur oxides, formaldehyde, carcinogens such as benzo[a]pyrene, volatile organic compounds (VOC), polycyclic aromatic hydrocarbons (PAH) and particulate matters (PM) may increase burden of respiratory symptoms and significantly exacerbate ongoing disease processes. An estimate of more than 1.6 million premature deaths annually was caused by indoor air pollution-related health problems such as chronic obstructive pulmonary disease (COPD), cancer, and respiratory infections including pneumonia and tuberculosis. Another dimension of the health problem due to smoke pollution was low-birth-weight among infants (Boman C. et al., 2006).

Among those by-products flown from the incomplete combustion of wood, particulate matters --known as solid and/or liquid fine particles suspended in the air-were one important health risk air pollution substance. They might be viable such as bacteria, fungi, moulds, and spores or non-viable particulates including substances of organic compounds, dust, metals, and salts (Stoker HS., Seager SL., 1976; Nigel B. et al. (2000). Depending on their sizes, density, shapes, their tendency to aggregate, and the force of their impact upon surfaces, particulate matters might be deposited in the upper parts or otherwise deep down in the lower parts of the respiratory tract. Due to its size, $\mathrm{PM}_{10}$ (Particulate Matters of $10 \mu \mathrm{m}$ and smaller) were small enough that they might enter the lower parts of the respiratory tract and deposited in the alveoli. Even, particulates less than 2.5 microns in diameter $\left(\mathrm{PM}_{2.5}\right)$, could penetrate deeper into the lungs and crossed into blood circulation system (McCracken, \& Smith, K. R., 1998).

\section{Methods}

The action-research began with an observational cross-sectional data collection in three Sub-districts of Nunkolo, Oinlasi, and Kuanfatu, District of TTS, NTT Province, Indonesia. A sample of 300 children under-five including infants living in traditional huts was taken randomly from lists provided by the village chiefs in the three Subdistricts. Data were collected from August to September 2013 using a set of questionnaires to obtain basic information on social, economic, basic sanitation facilities, characteristics of children under five including infants, and their health status. Considering local language barrier, local interviewers were trained and supervised to do the interview mothers or other family member of the selected participants.

Measurement of the level of indoor air pollutant concentrations was done using a DustTrak-monitor that examine PM10 concentrations over the height of 0.5 meters and 1.5 meters inside ten participating huts. The two heights were selected to represent the approximate heights of the participating adults squatting (and/or children standing) and adults standing around the stove.

Another data of carbon monoxide (CO) concentrations in 90 randomly chosen huts were also examined using a ToxiRAE gas detector. The $\mathrm{CO}$ measurements were chosen since CO measurements were an accurate way of estimating PM2.5 (Particulate Matters of 2.5 ? $\mathrm{m}$ and smaller) concentration in smoke. Like CO, PM2.5 had the potential of penetrating the alveoli in the lung.

Other than measuring the level of indoor air pollution and collecting basic healthrelated data, a basic health education program and a modification of the inner parts of the traditional huts by applying a room-partition and chimney were done. To build a better communication with the villagers, the method of conveying the content of the 
health education program was done in an informal gathering guided by a member of the research team with the villagers attending. The gathering included conversations to understand their perception of the health impacts of exposures to indoor smoke. Questions and answers with the participants were raised on general issues of public health including topics of general health problems of the participants and annoyances of smoke in Ume Kbubu experienced by the family. The help of interpreters was very useful since the language for daily conversation used by the villagers was the local tribal language Dawan.

Another informal communication with some interested local villagers (heads of the village, teachers, a pastor, and some young men) was also done in preparing the necessary steps in building the room-partition and the application of chimney on the stoves in the traditional huts. These informal communications were intended to build a friendly understanding between the research team member and the local community members and to prove their working capacity and knowledge on the basic health problems of smoke inside the hut. The discussion was also done in the planning of the use of working forces, planning and scheduling of work, selecting the appropriate materials to be used for fireplace, stove, chimney, and partition as part of an appropriate technology application. In short, the focus of this informal communications was to build understanding and willingness of the local people to participate in improving their health about indoor smoke pollution in their huts. The research team then worked together with the local villagers to build fireplace stoves with chimney and partition. During the activities in the field, weather changes were unpredictable, and the terrain was tough for the mobility of the working team. Other challenges were limited source of electricity, logistics and common daily needs, and the below-standard condition of the basic sanitation facilities.

\section{Results and Discussion}

Nunkulu and Oinlasi were two areas located in the mountainous grounds of Timor Tengah Selatan District while Kuanfatu laid on a basin-shape of a high ground area. The places were always had cool weathers except during the dry season. The public services were typical for small remote villages. The areas can be reached through a ruined rural road with loose rocks and mud through the mountainous grounds. At the time of the research, Oinlasi and Kuanfatu had their electricity service for the entire day while Nunkolo was served with electricity only during nights.

\subsection{Indoor Smoke Pollution}

Most of the inhabitants of the villages were farmers (93.3\%), while the others were drivers, labourers, vendors, clergymen and government employee. They lived in traditional dome-shape single room huts of approximately 4 meters diameter with no sufficient facilities for ventilation except from a single small opening of approximately 1 meter high and $70 \mathrm{~cm}$ wide of an entrance of the hut. Inside, in the middle of the floor, a traditional simple three-stone stove was always used for burning woods for a whole day every day producing smoke from an incomplete combustion. Regardless of the thickness of smoke inside the hut, no chimney or any sufficient opening was there in the huts to drive away the smoke. An only small portion of the smoke slowly seeped through the thatched roof of palm leaves, twigs, and grass covering the hut. The wood burning stove was primarily used for cooking and warming the room, and the smoke was also intended for preserving stalks of dried corn hung randomly over the hut. 
Corn was the major staple food in the villages. Sometimes it was combined with alternative food such as sweet potatoes, cassava, sago, or rice. The roof was blackened by the daily smoke from the open wood fire, making it a reliable evidence of a slow exposure to prominent levels of indoor smoke pollution. The floor inside was only the hardened earth covered with some remnants of ashes. The single room of the hut was the place where all the family's indoor activities took place. Children and babies usually stay around the stove while their mothers are busy with cooking. With the stove lit all day long from day to day, smoke was nearly always thick inside the huts. Consequently, women, - usually responsible for cooking-, and young children were exposed to elevated levels of dangerous indoor air pollution every day (Figure 2).

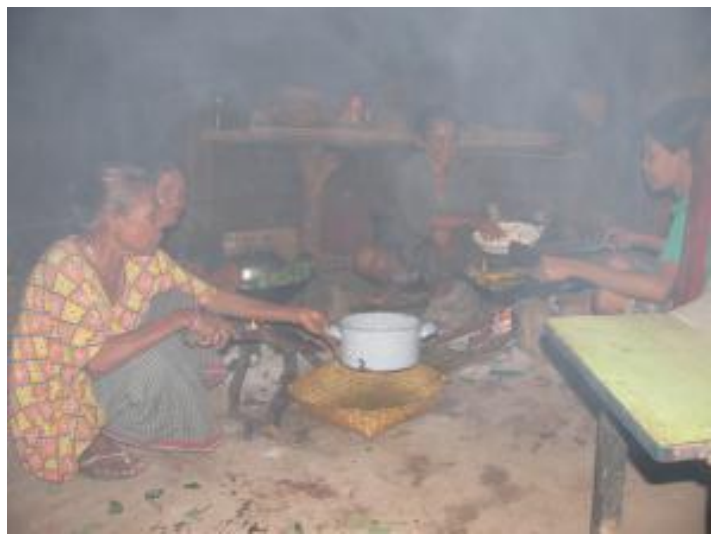

Fg. 2 Women cooking inside the hut

Source: photo archive from Purwana R., et al., 2013

Exposure to the smoke in this action research refers to the concentration of smoke in the immediate breathing environment, i.e. squatting to standing position in the hut during a specified period. With the application of a chimney or smoke hood over the stove, it was intended that the smoke was 'collected' and lead to flow directly to the upper part of the room higher than the immediate breathing environment so that it reduced the chance of smoke exposure to the inhabitants. Besides, by the accumulation of the smoke in the upper part of the room, it would preserve the corns hung there.

An assessment of $\mathrm{PM}_{10}$ concentrations inside ten participating huts showed a higher concentration of $\mathrm{PM}_{10}\left(9,690 \pm 8,800 \mu \mathrm{g} / \mathrm{m}^{3}\right)$ at the height of $11 / 2$ meter as compared to $4,390 \pm 5,820 \mu \mathrm{g} / \mathrm{m}^{3}$ at the height of $1 / 2$ meter examination points. This finding revealed that smoke from the stove tends to pack into the higher part of the hut, and the figures exceeded guideline levels of 24-hour mean PM10 levels in the range either 300-3,000 $\mu \mathrm{g} / \mathrm{m}^{3}$ (Bruce $\mathrm{N}$ et al., 2000) or $500 \mu \mathrm{g} / \mathrm{m}^{3}, 24$-h average (Vallero DA., 2008).

From the examination of carbon monoxide (CO), range values between a maximum concentration of $240.00 \mathrm{ppm}$ and a minimum concentration of $4.00 \mathrm{ppm}$ with a mean concentration of $86.2 \pm 53.42 \mathrm{ppm}$ were found. These levels might create significant health risks to the inhabitants. As a colourless, non-irritant, odourless and tasteless toxic gas produced by the incomplete combustion of wood, $\mathrm{CO}$ was a serious threat to health because in the human body it formed a compound, carboxyhemoglobin ( $\mathrm{COHb})$ that reduced the ability of haemoglobin to transport oxygen necessary for normal metabolism. To address the risk of long-term exposure the research referred to the guideline concentration for 24 hours exposure of $C O$ of $7 \mathrm{mg} / \mathrm{m}^{3}$ or $6.11 \mathrm{ppm}$ (Penney, et al., 2010; SKC., 2014; WHO, 2000; Stoker HS., Seager SL., 1976) or $46 \mathrm{mg} / \mathrm{m}^{3}$ (15 ppm), 8-h average (Vallero DA., 2008). 
The huts were usually over-crowded. Of the 299 respondents, 213 huts $(71.2 \%)$ were inhabited by 1 to 5 members of a family, while 86 huts $(28.8 \%)$ were occupied by 6 to 11 persons. No separate room was there in the huts, and the whole family member stayed and rested in the same single room huts.

\subsection{Water Sources}

More than half of the respondents $(59.0 \%)$ collect water from a spring. The rest obtained clean water either from the river, rain or in Kuanfatu from tap water. Water was collected by mothers, children, and sometimes by other members of the family. Among the respondents, $64.7 \%$ had to walk more than 100 meters for water collection, journeying through a challenging terrain.

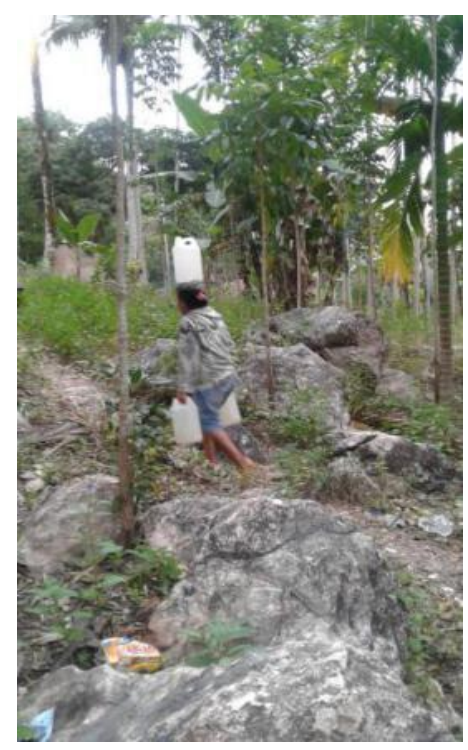

Fg. 3 A woman carrying water from spring

Source: photo archive from Purwana R., et al., 2013

Table 1. General characteristics of the respondents

\begin{tabular}{|c|c|c|}
\hline & $\begin{array}{c}\text { Frequency } \\
(\mathrm{N})\end{array}$ & $\begin{array}{c}\text { Percent } \\
(\%)\end{array}$ \\
\hline Number of respondents & 300 & 100 \\
\hline \multicolumn{3}{|l|}{ Occupations } \\
\hline Farmer & 280 & 93,3 \\
\hline Vendor & 4 & 1,3 \\
\hline Driver & 4 & 1,3 \\
\hline laborer & 1 & 0,3 \\
\hline Others (clergymen, government employee) & 11 & 3,7 \\
\hline \multicolumn{3}{|l|}{ Number of family members (persons) } \\
\hline $1-5$ & 213 & 71,2 \\
\hline $6-11$ & 86 & 28,8 \\
\hline Missing System & 1 & \\
\hline \multicolumn{3}{|l|}{ Sources of clean water } \\
\hline Spring water & 177 & 59.0 \\
\hline River water & 5 & 1.7 \\
\hline Tap water (only in Kuanfatu) & 24 & 8.0 \\
\hline Mix sources (spring, river, tap, and/or rain) & 94 & 31.3 \\
\hline
\end{tabular}


Rachmadi P., Budi H., Omega DR T. | ASEAN Journal of Community Engagement | Volume 1, Number 2, 2017

$\begin{array}{lrr}\text { Distances of water collection journey } & & \\ \quad \text { Up to100 meters } & 106 & 35.3 \\ \quad \text { More than } 100 \text { meters } & 194 & 64.7 \\ \text { Water carriers } & 13 & 4,3 \\ \quad \text { Children } & 49 & 16,3 \\ \quad \text { Mothers } & 88 & 29,3 \\ \quad \text { Mothers \& children } & 150 & 50.0 \\ \quad \text { Help from other family members }\end{array}$

Source: Purwana et al., 2012

In the three Sub-districts of Nunkolo, Oinlasi and Kuanfatu, most of the village people had their dug-hole latrines; the rest used the open fields. The latrines were placed outside of their huts.

\subsection{Partition and chimney}

Most of the respondents (99.3\% out of 287 respondents) are concerned with the indoor smoke and complained about its effects of irritating eyes, coughs, short of breath, and potential illnesses.

Intervening to the problem, a suggestion of applying partition and chimney over the stove was positively accepted by 215 persons $(75.7 \%)$ out of 284 respondents. The rest were in doubt to adopt the change, worried that it would disturb the preservation of corns. These arguments were nevertheless accommodated since the proposed intervention was a preventive measure method with its benefits only could be realized in the distant future (Emmelin, A., Wall, S. 2007).

Table 2. Willingness to modify stove

\begin{tabular}{|c|c|c|}
\hline Number of respondents & $\begin{array}{l}\text { Frequency } \\
\text { (n) } \\
\quad 300 \\
\end{array}$ & $\begin{array}{c}\text { Percent } \\
(\%) \\
100\end{array}$ \\
\hline \multicolumn{3}{|l|}{ Willingness to have a chimney } \\
\hline No & 69 & 24,3 \\
\hline Yes & 215 & 75,7 \\
\hline Missing System & 16 & \\
\hline \multicolumn{3}{|l|}{ Willingness to use biogas } \\
\hline No & 200 & 67.1 \\
\hline Yes & 98 & 32.9 \\
\hline Missing System & 2 & \\
\hline
\end{tabular}

Source: Purwana et al., 2012

Of the many possibilities, a hearth-like structure representing a model for constructing a chimney over a stove attached to the partition had been built and shown its effectiveness in driving the smoke into the chimney. Hence, reducing the thickness of smoke at the lower-part area inside five chosen traditional huts (Purwana et al., 2013). Nevertheless, from the discussion later with the other local people, they expressed their objection that the hearth-like structure took more space than expected. 


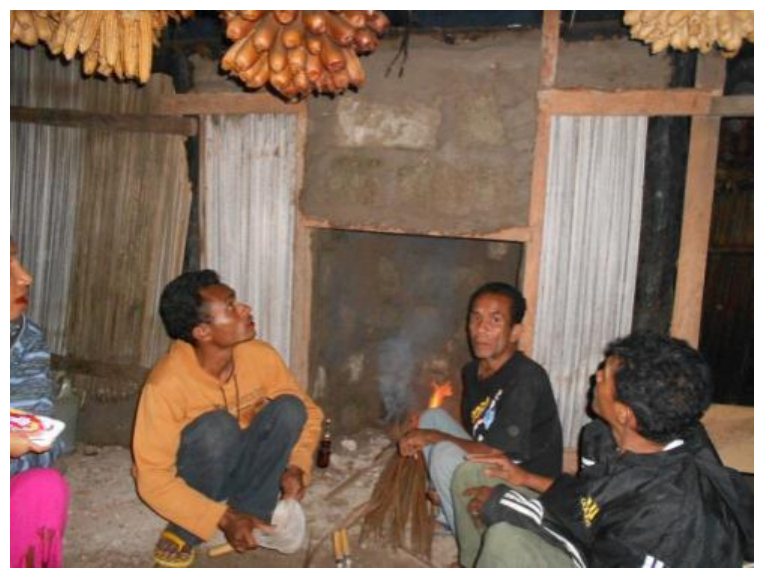

Fg. 4 Testing the flow of smoke through the chimney Source: photo archive from Purwana R., et al., 2013

A positive response also came from the participating villagers suggesting an alternative design of applying the chimney combined with a ceiling for storing the corn. The idea was that it would drive the smoke into the attic and flew through small smoke stacks on the roof. Another suggestion is to utilize local materials such as clay, gravels, and partition made of 'bebak' (a plane made of midribs of the palm leaves attached)

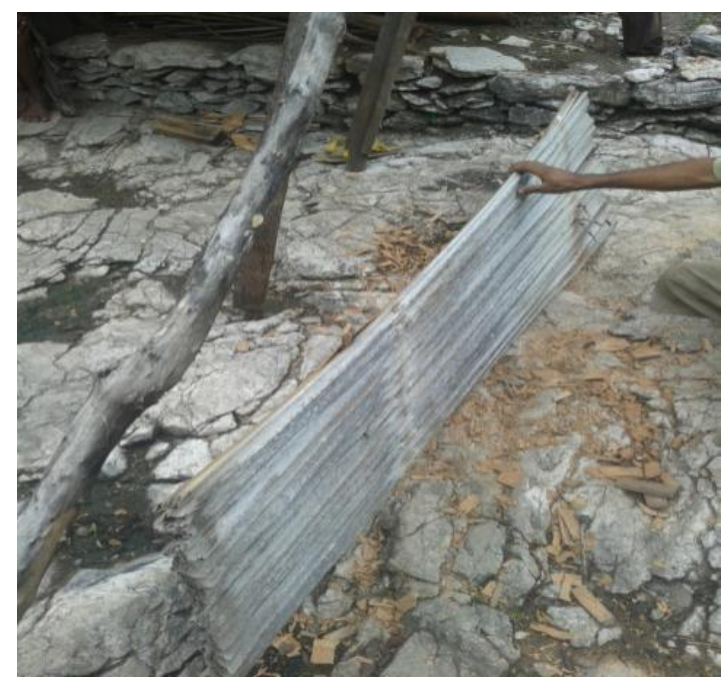

Fg. 5 Bebak

Source: Purwana et al., 2012

At least, from the cooperative work between some local key persons and the research team, three designs of chimneys were agreed and thought out to be considered in the future. 


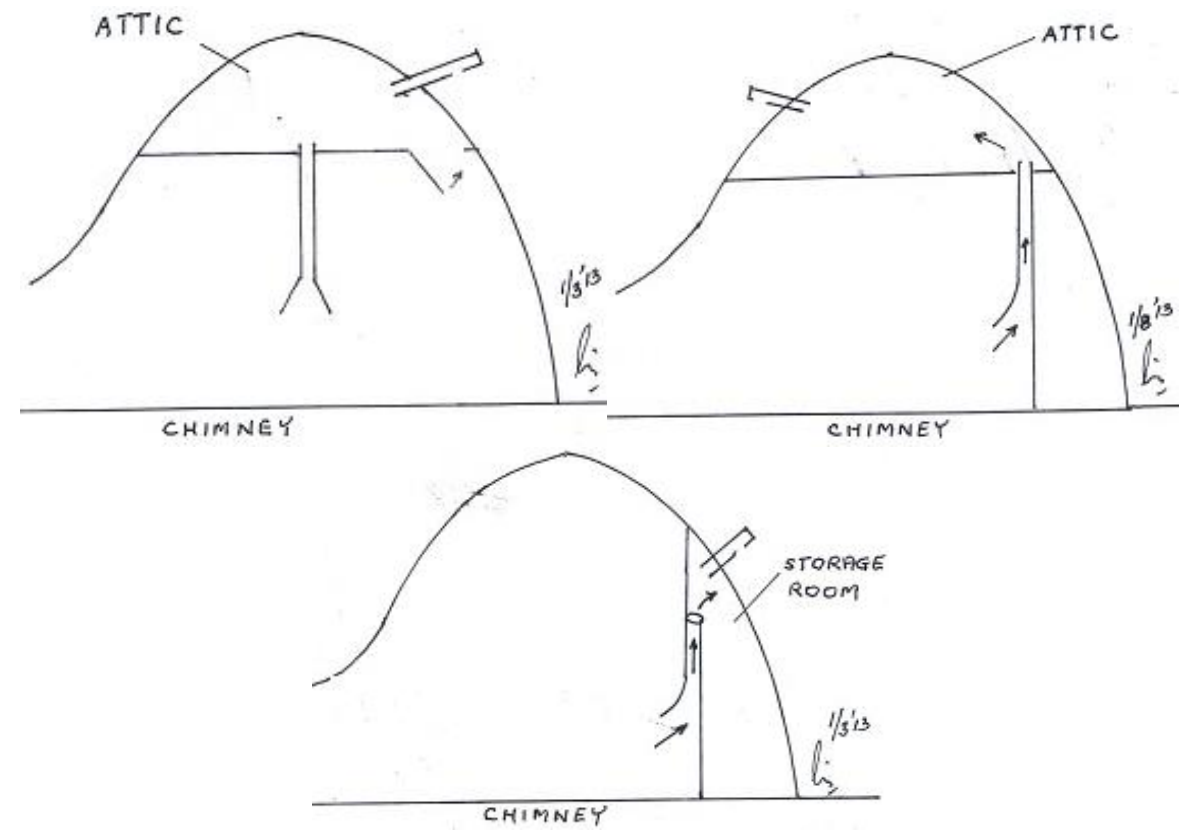

Fg. 6 Designs of Partition and Furnace in Traditional Huts, NTT. Source: photo archive from Personal Pictures

\section{Conclusions}

The main goal of the present intervention was to probe the acceptance of the villagers in NTT to alleviate the exposure to indoor air pollution with a simple technology in the attempt of mitigating ARI among the inhabitants of Ume Kbubu. This was done through the manipulation of indoor environment by applying a simple technology of partitioning the room and providing smoke hood or chimneys over their traditional stoves together with health education and discussion with key persons in the villages.

Though other means of reducing indoor air pollution exist, such as cleaner fuels, improved stoves, or behavioural changes, considerations should be made to meet the domestic local energy scheme, the understanding on health risk factors, and cultural demands including the preservation of corns by smoke. Also, the economy is another barrier to the adoption of cleaner fuels since fire-woods are readily available for free in the vicinity.

Regarding domestic local energy scheme, although biogas, charcoal, or another choice of fuel/energy sources might have less smoke than wood, the villagers seemed reluctant to replace wood as their source of energy. Therefore, a slow pace of development in the area suggests that wood for fuel would continue to be used by the native for many years to come. These facts needed a more comprehensive approach and understanding since the community did not have adequate understanding about smoke as adverse health factor for ARI. The application of smoke hood over the traditional stoves was more needed. A more intensive health education on the danger of smoke towards the lung was also required.

Moreover, the strong attachment of the villagers to the cultural demands and their dependency on smoke to preserve corn as their main staple food is another crucial issue. However, another way of preserving corn other than smoke was known in other parts of the country.

At this stage, the present action of a simple and affordable model for intervention by applying partitions and smoke hood or chimneys on stoves was quite successfully 
accepted by some members of the villagers. This was a good and promising start for the change in the traditional way of life of the community. Health education and communication done by a method that was agreeable to the community were done well. Innovations were raised among the participated villagers in making alternative fireplace design and using the local materials easily found in the place. Therefore, it was necessary to arouse the willingness of the other members of the villager to participate. At this point, this achievement convinced the research team that the effort to reduce the problem of indoor air pollution in the Traditional Huts in TTS District had its benefits and needed a follow-up action.

\section{Acknowledgement}

This study was funded by Directorate for Higher Education, Ministry of the Education Republic of Indonesia through a grant to the Directorate for Research and Public Service, Universitas Indonesia. The authors would like to thank the support and assistance of the Dean, Faculty of Public Health, Universitas Indonesia; Head, Department of Environmental Health, Faculty of Public Health, Universitas Indonesia; Local Government of Nusa Tenggara Timur Province; District Office of Timor Tengah Selatan; Local people of Nunkolo, Oinlasi, and Kuanfatu in the District Timor Tengah Selatan.

\section{References}

Boman C., Forsberg B., and Sandstrǒm T. (2006). Shedding new light on wood smoke: a risk factor for respiratory health. Eur Respir J 2006; 27: 446-447.

Bruce N., Perez-Padilla R., Albalak R. (2000). Indoor air pollution in developing countries: a major environmental and public health challenge Bull World Health Organ vol.78 n.9 Genebra Jan. 2000

Depkes (2007). Riset Kesehatan Dasar (Basic Health Research). Departemen Kesehatan Republik Indonesia

Depkes (2010). Riset Kesehatan Dasar (Basic Health Research), 2010. Departemen Kesehatan Republik Indonesia

Denny FW., Loda FA. (1986). Acute respiratory infections are the leading cause of death in children in developing countries.Am J Trop Med Hyg. 1986 Jan;35(1):1-2.

Diaz JV., Koff J., Gotway MB., Nishimura S., Balmes JR. (2006). Case Report: A Case of Wood-Smoke-Related Pulmonary Disease Environ Health Perspect 114:759-762 (2006). doi:10.1289/ehp.8489 available via http://dx.doi.org/ [Online 24 January 2006]

Dinkes TTS (2007). Health Service Office Profile Sub-district Timor Tengah Selatan (Profil Dinas Kesehatan Kabupaten TTS Tahun 2007).

Emmelin A., Wall S. (2007). Indoor Air Pollution, A Poverty-Related Cause of Mortality Among the Children of the World. CHEST 2007; 132:1615-1623 
Rachmadi P., Budi H., Omega DR T. | ASEAN Journal of Community Engagement | Volume 1, Number 2, 2017

Gold JA., Jagirdar J., Hay JG., Addrizzo-Harris DJ., Naidich DP., Rom WN. (2000). Hut lung. A domestically acquired particulate lung disease. Medicine (Baltimore) 2000 Sep: 79(5): 310-7

Grobbelaar JP., Bateman ED. (1991). Hut lung: a domestically acquired pneumoconiosis of mixed aetiology in rural women Thorax 1991; 46: 334-340

McCracken, Smith KR. (1998). Emissions and Efficiency of Improved Wood burning Cookstoves in Highland Guatemala. Environmental International, Vol.24, No7, pp. $739-47,1998$

Nigel B., Perez-Padilla R., Albalak R. (2000). Indoor air pollution in developing countries: a major environmental and public health challenge. Bulletin World Health Organization vol.78 n.9 Genebra Jan. 2000

Penney et al. (2010) Carbon monoxide. In: WHO Guideline for Indoor Air Quality: Selected Pollutants (2010). World Health Organization Regional Office for Europe

Purwana R., Hermawati E., Tahun ODR. (2012). Indoor Air Quality as a Risk Factor of ARI in Children Under-five in Nusa Tenggara Timur (A Research Report in Indonesian: Kualitas Udara Dalam Rumah Masyarakat Adat sebagai Faktor Risiko Kejadian Penyakit ISPA pada Anak Berumur sampai dengan Lima Tahun di Nusa Tenggara Timur), Universitas Indonesia, 2012

Purwana R., Hartono B., Tahun ODR., Abidin N. (2013). Empowerment of Villagers in the Development of Healthy and Environmental Friendly Traditional Huts (Ume $K b u b u$ ) in Hoineno Village, Nusa Tenggara Timur Province (A CEGs Research Report in Indonesian: Pemberdayaan Masyarakat Desa Hoineno, Propinsi Nusa Tenggara Timur dalam Pengembangan Model Rumah Masyarakat Adat ( Rumah Bulat) yang Sehat dan Ramah Lingkungan) Universitas Indonesia, 2013

Schiller WR., Burn Care in Inhalation Injury (2000). In: Textbook of Critical Care. Grenvik A., Ayres SM., Holbrook PR., Shoemaker WC. (eds). W.B. Saunders Coy. Philadelphia, USA. pp. 365-377.

SKC. World Leader of Sampling Technologies (2014) http://www.skcinc.com/converter/converter.asp

Smith KR., Corvalán CF., Kjellström T. (1999). How Much Global Ill Health Is Attributable to Environmental Factors? In Epidemiology Resources, September 1999, Vol. 10 No. 5: 573-584

Stoker HS., Seager SL. (1976) Environmental Chemistry: Air and Water Pollution, Scott, Foresman and Coy.

Vallero DA. (2008). Fundamentals of Air pollution $4^{\text {th }}$ ed. Elsevier inc.

UNEP \& WHO (2010). Healthy Environments for Healthy Children, key messages for action. WHO Library Cataloguing-in-Publication Data. Printed in France 
98

Rachmadi P., Budi H., Omega DR T. | ASEAN Journal of Community Engagement | Volume 1, Number 2, 2017

WHO (2000). Air Quality Guidelines for Indoor Europe, 2nd ed., World Health Organization Regional Publications, European Series, no. 91. Copenhagen, Denmark.

WHO (2010). Guideline for Indoor Air Quality: Selected Pollutants. World Health Organization Regional Office for Europe

WHO-UNICEF (2004). WHO-UNICEF Joint Statement. Management of pneumonia in community setting. World Health Organization, United Nation Children's Fund. 